\title{
FERMENTATIVE PROFILE AND NUTRITIONAL VALUE OF OLIVE BAGASSE SILAGE WITH FEED ADDITIVES
}

\author{
PERFIL FERMENTATIVO E VALOR NUTRICIONAL DA SILAGEM DE \\ BAGAÇO DE AZEITONA COM ADITIVOS ALIMENTARES
}

\section{Neliton Flores KASPER ${ }^{1}$; Gabriela Ceratti HOCH ${ }^{1}$; Othon Dalla Colletta ALTERMANN ${ }^{1}$; Fabiane Quevedo da ROSA ${ }^{2}$; Leonardo Ereno TADIELO ${ }^{3}$; Luana Costa POLO ${ }^{1}$; Ricardo Pedroso OAIGEN ${ }^{4}$; Eduardo Bohrer de AZEVEDO ${ }^{5}$; Deise Dalazen CASTAGNARA ${ }^{4}$}

1. Médicos Veterinários, Universidade Federal do Pampa, UNIPAMPA, Uruguaiana, RS, Brasil. nelitonfloreskasper@hotmail.com; 2. Discente, Doutorado do Programa em Ciência Animal, Universidade Federal do Rio Grande do Sul, UFRGS, Porto Alegre, RS, Brasil; 3. Discente, Programa de Pós-Graduação em Ciência Animal, Universidade Federal do Paraná, UFPR, Setor Palotina, PR, Brasil; 4. Prof $^{(a)}$. Dr ${ }^{(a)}$., Curso de Medicina Veterinária, Universidade Federal do Pampa, UNIPAMPA, Uruguaiana, RS, Brasil; 5. Prof. Dr., Curso de Agronomia, Universidade Federal do Pampa, UNIPAMPA, Itaqui, RS, Brasil.

\begin{abstract}
The aim of this study was to measure the chemical composition, microbiological profile, fermentative characteristics and the aerobic stability of the olive bagasse silages in natura and added with corn bran, soybean and rice bran in different times of sampling. The was completely randomized design in arrangement of plots subdivided in $4 \times 3$ time, with five replications. In the plots were allocated the main treatments, and in the subplots the sampling times were allocated. The fermentative characteristics was studied by determination of the dry matter $(\mathrm{DM})$ content, $\mathrm{pH}$ and ammoniacal nitrogen $\left(\mathrm{NH}_{3}-\mathrm{N}\right)$, the microbiological by determining the populations of filamentous fungi, Clostridia, lactic acid bacteria and enterobacteria. In the nutrient profile study, the contents of mineral matter $(\mathrm{MM})$, organic matter $(\mathrm{OM})$, crude protein $(\mathrm{CP})$, ether extract (EE), neutral detergent fiber (NDF), acid detergent fiber (ADF), lignin, cellulose, hemicellulose, nitrogen bound to acid detergent fiber (NIDA), nitrogen bound to neutral detergent fiber (NIDN), carbohydrate and total digestible nutrient (TDN). At the ensilage moment, it also has been determined in vitro dry matter digestibility (IVDMD) and in vitro digestibility of organic matter (IVDOM). The use of corn and rice bran provided a better fermentative profile in the studied ensilage. The $\mathrm{pH}$ of the silages added corn and rice bran has presented in 4.00 and 4.06 after 112 storage days, consequently. The adding of soybean bran provided the greatest CP values and non-fibrous carbohydrates (NFC) after the fermentative period, been it $131.55 \mathrm{~g} \mathrm{~kg}^{-1}$ of $\mathrm{DM}$ for CP and $176.28 \mathrm{~g} \mathrm{~kg}^{-1}$ of DM for NFC. The treatments without bran adding and rice bran added have demonstrated IVDOM levels of $581.12 \mathrm{~g} \mathrm{ka}^{-1}$ od DM and $604.51 \mathrm{~g} \mathrm{~kg}^{-1}$ of DM, consequently. The studied meals improve the nutritional profile of the studied silages and are potentially usable as additives in olive bagasse silages.
\end{abstract}

KEYWORDS: Byproduct. Ruminants. Nutritional value. Silage.

\section{INTRODUCTION}

In the industrial processing of olives to obtain the oil there is intense generation of residues with potential of environmental contamination, estimated at $800 \mathrm{~kg}$ for $1000 \mathrm{~kg}$ of processed olives (ALCAIDE; RUIZ, 2008). Of these, approximately $500 \mathrm{~kg}$ is equivalent to an aqueous residue and 300 $\mathrm{kg}$ is equivalent to a semi-solid residue, called olive bagasse (NIAOUNAKIS; HALVADAKIS, 2006).

In nutritional characterization, the olive bagasse was considered of low nutritional value (NASOPOULOU; ZABETAKIS, 2013), compared in terms of energy and protein to that of other cultural residues. However, olive cultivation adapts to regions with low annual rainfall and critical temperatures (ABAZI et al., 2012), in which livestock activities with ruminants can also be developed. In these situations, due to the soil and climatic conditions unfavorable to forage growth in certain periods of the year, livestock systems pass annually for critical periods in the feeding of animals, with losses to cattle ranchers.

With the use of olive bagasse, in addition to the reduction of animal feed costs to cattle ranchers (NASOPOULOU; ZABETAKIS, 2013) and waste treatment to agroindustries (OMAR et al., 2012). The livestock production systems would become more sustainable by the less dependence of traditional and expensive food systems that include noble foods and for potential human consumption (NASOPOULOU; ZABETAKIS, 2013). The 
Fermentative profile...

moderate inclusion of olive bagasse in ruminant diets may be an advantage for reducing methane emissions (KONDO et al., 2014), with limitations in diets in $100 \mathrm{~g} \mathrm{~kg}^{-1}$ of DM (JAYANEGARA et al., 2011).

However, this by-product has its production concentrated in only one season of the year, with the need for storage in the property. This is hampered by the high moisture content of the material, but it can be accomplished by ensilage. This alternative is accessible and economical (SANSOUCY et al., 1985) when applied to the conservation of agroindustrial by-products (MOKHTARPOUR et al., 2012).

The ensilage preserves the food by anaerobic fermentation with the reduction of the $\mathrm{pH}$ of the ensiled mass. However, in order to be safe, it requires the presence of soluble carbohydrates, low buffer capacity and dry matter content in the materials to be ensiled between $300 \mathrm{~g} \mathrm{~kg}^{-1}$ and $350 \mathrm{~g}$ $\mathrm{kg}^{-1}$ (MCDONALD et al., 1991). Olive bagasse does not have these characteristics (SANSOUCY et al., 1985), but this absence can be overcome with the use of food additives (NERES et al., 2013). However, as the interaction between residues and additives can be very dynamic within the silos during the biochemical processes of ensilage, the nutritional characterization of the material obtained should proceed after the fermentation (AZEVÊDO et al., 2011).
KASPER, N. F.

In this sense, the objective of this study was to evaluate the fermentation, nutritional value, populations of microorganisms and the aerobic stability of olive bagasse silages in natura or additiveded with corn, soybean and rice bran.

\section{MATERIAL AND METHODS}

The experiment was carried at TECNOLIVAS $®$ Indústria/Pomares located in the municipality of Caçapava do Sul, Rio Grande do Sul, Brazil and at the Animal Nutrition Lab of Unipampa - Uruguaiana Campus, located at latitude: $29^{\circ} 45^{\prime} 17$ "S and longitude: $57^{\circ} 05^{\prime} 18^{\prime \prime} \mathrm{W}$, at an altitude of $66 \mathrm{~m}$. It was used a completely randomized design in arrangement of plots $4 \times 3$ with five repetions. In the plots, the silages studied were: silage bagasse in natura (Bagasse) or added with corn (Bagasse + corn), soybean (Bagasse + soybean) and rice (Bagasse + rice) and the sampling times at the subplots: In the moment of ensilage (Ensilage), at 112 days after ensiling (Aperture) and after seven days of aerobic exposure (Stability).

Aiming to product silages with DM of $330 \mathrm{~g}$ $\mathrm{kg}^{-1}$, the mixtures were prepared based on the natural matter in the ratio of 93 parts of fresh bagasse to seven parts of bran, based on the contents of DM determined in an oven (Table 1).

Table 1. Chemical composition of olive bagasse in natura and additives used in the treatments.

\begin{tabular}{lcccc}
\hline \multicolumn{4}{c}{ Additives used in the composition of silages } \\
\hline Variables & In natura olive bagasse & Rice bran & Soybean bran & Corn bran \\
\hline Dry matter $\left(\mathrm{g} \mathrm{kg}^{-1}\right)$ & 289.53 & 862.92 & 833.50 & 886.33 \\
Mineral matter* & 32.60 & 109.94 & 67.91 & 11.56 \\
Organic matter* & 965.42 & 890.12 & 932.13 & 988.53 \\
Crude protein* & 50.54 & 126.33 & 450.32 & 88.74 \\
Neutral detergent fiber* & 602.51 & 248.22 & 270.66 & 99.95 \\
Acid detergent fiber* & 562.41 & 137.63 & 122.86 & 54.43 \\
Ether extract* & 242.72 & 183.21 & 33.97 & 41.43 \\
Lignin* & 355.75 & 53.87 & 23.04 & 29.12 \\
Total carbohydrate* & 672.26 & 580.63 & 447.96 & 858.45 \\
Non-fibrous carbohydrates* & 120.93 & 332.43 & 177.34 & 758.52 \\
Fibrous carbohydrates* & 553.12 & 248.25 & 270.68 & 99.97 \\
\hline
\end{tabular}

* Variables expressed on the basis of dry matter.

The mixtures were homogenized manually and conditioned in experimental silos made with polyvinyl chloride (PVC) pipes $50 \mathrm{~cm}$ high and 10 $\mathrm{cm}$ in diameter. In each silo was added $3,900 \mathrm{~kg}$ of the mixture, equivalent to a silage density of $900 \mathrm{~kg}$ $\mathrm{m}^{-3}$. The silos were sealed with caps equipped with Bunsen type valves for the free escape of the gases fixed with the aid of adhesive tape. For the drainage of the effluent produced, $0.5 \mathrm{~kg}$ of dried and autoclaved sand, insulated by a cotton cloth, was conditioned at the bottom of each silo.

The temperature of the silages during the first week of fermentation was measured with a spittype thermometer inserted inside the silos by means 
of a rubber valve coupled to the silos. In the silos unloaded after 112 days, the upper and lower portions of each silo were discarded $(5 \mathrm{~cm})$, with posterior homogenization and sampling of the remaining silage to study the fermentation profile, microbiological, bromatological and aerobic stability of the silages. The fermentative characteristics was studied by determination of dry matter, $\mathrm{pH}$ and ammoniacal nitrogen, been the previous item determined in relation to the total nitrogen $\left(\mathrm{NH}_{3}-\mathrm{N} / \mathrm{TN}\right)$ in the ensilage, at 112 days of fermentation and at the aerobic stability.

To accomplish the study of aerobic stability, a $350 \mathrm{~g}$ silage sample was submitted to air exposure and had its $\mathrm{pH}$ and temperature values monitored daily for seven days. On the seventh day after the exposure of the material to air, bromatological and microbiological analysis were accomplished and the fermentative profile regarding to the stability of the silages was studied. The temperature of the silages and the environment was measured with a digital spit-type thermometer while $\mathrm{pH}$ was determined according to Silva and Queiroz (2009). The time taken by the silages to demonstrate temperature rise in $1{ }^{\circ} \mathrm{C}$ over the environment temperature was considered as an aerobic stability break (DRIEHUIS et al., 2001) and/or $\mathrm{pH}$ rising in 0,2 unites of $\mathrm{pH}$ relating to opening of the silos.

The pre-drying was determined in samples of $300 \mathrm{~g}$, by drying in oven with forced circulation of air under a temperature of $55^{\circ} \mathrm{C}$ for 72 hours. The $\mathrm{pH}$ and $\mathrm{NH}_{3}-\mathrm{N}$ were determined in independent samples according to Silva and Queiroz (2009) and Bolsen et al. (1992), respectively.

The chemical composition was determined in the samples after obtaining the DM and milling in mill of Willey type knives with stainless steel chamber and sieve, with $1 \mathrm{~mm}$ mesh. It was determined the dry matter correction at $105{ }^{\circ} \mathrm{C}$ and the contents of organic matter (OM), mineral matter $(\mathrm{MM})$, crude protein $(\mathrm{CP})$, ether extract (EE) (SILVA; QUEIROZ, 2009), neutral detergent fiber (NDF), acid detergent fiber (ADF), lignin, cellulose and hemicellulose (VAN SOEST et al., 1991). Fractions of carbohydrates were estimated according to Sniffen et al. (1992).

The microbiological profile was studied through the determination of the microbial populations, according to Silva et al. (2007). After collection of samples these were homogenized and diluted in the proportion of $10 \mathrm{~g}$ to $90 \mathrm{~mL}$ of peptone water, obtaining a dilution of $10^{1}$ until $10^{8}$. Afterwards, the samples were inoculated in selective culture media. For the growth and counting of filamentous fungi and yeasts was used the Potato
Dextrose Agar media, maintaining the plates at room temperature for 5 to 7 days. For the Lactobacillus developing was used the Lactobacillus MRS Broth media in the oven at 35 ${ }^{\circ} \mathrm{C}$ for 48 hours, for the Enterobacteria developing the media Violet Red Bile Agar (Oxford) maintained at $35{ }^{\circ} \mathrm{C}$ for 72 hours, for the Clostridium developing was used the Reinforced Clostridial Agar media, maintained at $35{ }^{\circ} \mathrm{C}$ for 72 hours in anaerobic chamber. After the incubation period, colony forming units (CFU) that had between 30-300 CFU per Petri dish were counted, and the results were expressed as $\log _{10} \mathrm{CFU} \mathrm{g}{ }^{-1}$ of DM (MCDONALD et al., 1991).

For statistical data analysis, these were submitted to variability analysis and when the meaningfulness was stablished, the rate was compared according to Tukey test (5\%) with complex variance adoption due to subdivided plots, with the digestibility, $\mathrm{pH}$ and temperature data exception. The digestibility data were submitted to the variability analysis and when the meaningfulness was noticed, the rate was compared according to Tukey test $(5 \%)$. The $\mathrm{pH}$ and temperature data during the seven days aerobic stability were analyzed by the regression analysis, been linear and quadratic models tested. The chosen models was based in determination coefficients $\left(\mathrm{R}^{2}\right)$ and meaningfulness level (to a 5\% level) of the regression coefficients. All the analyses were carried out on Sisvar Statistic Program (FERREIRA, 2011).

\section{RESULTS AND DISCUSSION}

The additives increased the DM content of the mixtures and silages at the opening of the silos and after exposure to air (Table 2). In the ensiling, the olive bagasse presented DM content lower than that recommended by McDonald et al. (1991) which is $300 \mathrm{~g} \mathrm{~kg}^{-1}$ at $350 \mathrm{~g} \mathrm{~kg}^{-1}$ to provide adequate fermentation within the silo. During fermentation due to the production of effluents and after exposure to air due to loss of humidity to the environment, it was observed elevation in DM content (Table 2).

The addition of the rice bran increased the MM in the silages where it was added (Table 2), due to its content of MM (Table 1) and the amount of silica (VALADARES FILHO et al., 2006). The values of $\mathrm{MM}$ in in natura bagasse silage are consistent with those reported by Nefzaoui (1991), who found values between 30 and $50 \mathrm{~g} \mathrm{~kg}^{-1}$.

The EE in the silages was diluted with the inclusion of the additives in relation to the in natura olive bagasse silage (Table 2). The variations during 
Fermentative profile...

fermentation and after exposure to the air indicate that there was a great dynamics in the fermentative processes inside the silos, however, they do not characterize a disadvantage. Niaounakis and Halvadakis (2006) cite the EE content of olive bagasse (essentially lipids and polyphenols) as a barrier to anaerobic degradation thereof, which in the ensiling process could be characterized as a positive aspect for preservation of the ensiled mass.

This advantage could be observed in this study, where even with the dynamics observed for
KASPER, N. F.

the EE contents in the silages, through the fermentation process and the discrete changes in the OM contents (Table 2) indicate the non-occurrence of their degradation. This fact, together with the $\mathrm{pH}$ values obtained (Table 2), with the characteristic odor of well-fermented silages at the opening of the silos indicates the non-occurrence of decay of the ensiled mass.

Table 2. Chemical composition and $\mathrm{pH}$ values in silage from olive bagasse with feed additives in ensilage, at 112 days of ensiling and after seven days of aerobic exposure

\begin{tabular}{|c|c|c|c|c|c|c|c|c|}
\hline \multirow{3}{*}{ Silages } & \multicolumn{3}{|c|}{ Times } & \multirow{2}{*}{ Average } & \multicolumn{3}{|c|}{ Times } & \multirow{2}{*}{ Average } \\
\hline & Ensilage & Opening & Stability & & Ensilage & Opening & Stability & \\
\hline & \multicolumn{3}{|c|}{ Dry Matter $\left(\mathrm{g} \mathrm{kg}^{-1}\right)$} & \multicolumn{5}{|c|}{ Mineral Matter $\left(\mathrm{g} \mathrm{kg}^{-1}\right.$ of dry matter $)$} \\
\hline Bagasse & $289.51 \mathrm{Bc}$ & $300.51 \mathrm{Bc}$ & $323.03 \mathrm{Ac}$ & 304.35 & $32.68 \mathrm{Bb}$ & $35.83 \mathrm{Ac}$ & 33.30BAc & 33.94 \\
\hline Bagasse + Corn & $323.53 \mathrm{Cba}$ & $404.60 \mathrm{Ba}$ & $451.65 \mathrm{Aa}$ & 393.26 & $30.86 \mathrm{Ab}$ & $23.21 \mathrm{Cd}$ & $26.52 \mathrm{Bd}$ & 26.86 \\
\hline Bagasse + Soybean & $306.10 \mathrm{Ccb}$ & $350.05 \mathrm{Bb}$ & $370.26 \mathrm{Ab}$ & 342.14 & $44.67 \mathrm{Aa}$ & $44.11 \mathrm{Ab}$ & $44.45 \mathrm{Ab}$ & 44.41 \\
\hline Bagasse+Rice & $339.00 \mathrm{Ba}$ & $370.04 \mathrm{Ab}$ & $388.03 \mathrm{Ab}$ & 365.69 & $43.79 \mathrm{Ba}$ & $47.45 \mathrm{Aa}$ & $48.40 \mathrm{Aa}$ & 46.55 \\
\hline Average & 314.54 & 356.30 & 383.24 & & 38.00 & 37.65 & 38.17 & \\
\hline CV $1(\%)$ & \multicolumn{4}{|c|}{2.35} & \multicolumn{4}{|c|}{5.29} \\
\hline CV $2(\%)$ & \multicolumn{4}{|c|}{3.85} & \multicolumn{4}{|c|}{4.52} \\
\hline & \multicolumn{4}{|c|}{ Organic Matter ( $\mathrm{g} \mathrm{kg}^{-1}$ of dry matter) } & \multicolumn{4}{|c|}{ Ether Extract ( $\mathrm{g} \mathrm{kg}^{-1}$ of dry matter) } \\
\hline Bagasse & $965.47 \mathrm{Aa}$ & $962.05 \mathrm{Ab}$ & $964.02 \mathrm{Ab}$ & 963.85 & $242.75 \mathrm{Ca}$ & $323.92 \mathrm{Aa}$ & $295.91 \mathrm{Ba}$ & 287.52 \\
\hline Bagasse+Corn & $968.09 \mathrm{Ba}$ & $975.60 \mathrm{Aa}$ & $971.50 \mathrm{BAa}$ & 971.73 & $197.43 \mathrm{Cb}$ & $270.49 \mathrm{Ab}$ & $240.08 \mathrm{Bb}$ & 236.00 \\
\hline Bagasse + Soybean & $953.86 \mathrm{Ab}$ & 955.89Acb & $949.98 \mathrm{Ac}$ & 953.24 & $211.42 \mathrm{Ab}$ & $150.02 \mathrm{Bd}$ & $119.09 \mathrm{Cd}$ & 160.18 \\
\hline Bagasse+Rice & $956.21 \mathrm{Ab}$ & $951.05 \mathrm{Ac}$ & $950.51 \mathrm{Ac}$ & 952.59 & $154.10 \mathrm{Cc}$ & $188.33 \mathrm{Ac}$ & $174.12 \mathrm{Bc}$ & 172.18 \\
\hline Average & 960.91 & 961.15 & 959.00 & & 201.42 & 233.19 & 207.30 & \\
\hline CV 1 $(\%)$ & \multicolumn{4}{|c|}{0.37} & \multicolumn{4}{|c|}{4.21} \\
\hline CV $2(\%)$ & \multicolumn{4}{|c|}{0.44} & \multicolumn{4}{|c|}{4.00} \\
\hline \multicolumn{9}{|c|}{$\mathrm{pH}$} \\
\hline & \multirow{2}{*}{\multicolumn{4}{|c|}{$\begin{array}{r}\text { Times } \\
\text { Opening }\end{array}$}} & & & \multirow{2}{*}{\multicolumn{2}{|c|}{ Average }} \\
\hline Silages & & & & & \multicolumn{2}{|c|}{ Stability } & & \\
\hline Bagasse & \multicolumn{2}{|c|}{$5.18 \mathrm{Ab}$} & \multicolumn{2}{|c|}{$4.57 \mathrm{Aba}$} & & $71 \mathrm{BAb}$ & \multicolumn{2}{|r|}{4.82} \\
\hline Bagasse+Corn & \multicolumn{2}{|c|}{$5.37 \mathrm{Aba}$} & \multicolumn{2}{|c|}{$4.00 \mathrm{Bc}$} & & $.57 \mathrm{Aa}$ & \multicolumn{2}{|r|}{4.98} \\
\hline Bagasse+Soybean & \multicolumn{2}{|c|}{$5.78 \mathrm{Aa}$} & \multicolumn{2}{|c|}{$4.98 \mathrm{Ba}$} & & $.49 \mathrm{Aa}$ & \multicolumn{2}{|r|}{5.42} \\
\hline Bagasse+Rice & \multicolumn{2}{|c|}{$5.59 \mathrm{Aba}$} & $4.06 \mathrm{Bb}$ & & & $.34 \mathrm{Bb}$ & & 4.67 \\
\hline Average & 5. & & 4.40 & & & 5.03 & & \\
\hline CV $1(\%)$ & & & & 6.64 & & & & \\
\hline CV $2(\%)$ & & & & 6.40 & & & & \\
\hline
\end{tabular}

In relation to the $\mathrm{pH}$ values (Table 2) only the silages added corn and rice bran had $\mathrm{pH}$ values below 4.2; indicative of adequate fermentation to restrict the growth of undesirable microorganisms and food preservation for long periods according to Mcdonald et al. (1991). The difficulty on the $\mathrm{pH}$ reduction can be due to the low carbohydrate content present in the olive bagasse, approximately $100 \mathrm{~g} \mathrm{~kg}^{-1}$ of DM (NIAOUNAKIS; HALVADAKIS, 2006), this characteristic can be improved by the addition of high concentration starch bran (VALADARES FILHO et al., 2006), a fermentable substrate for multiplication of lactic acid bacteria (NERES et al., 2013). Another factor that hinders $\mathrm{pH}$ reduction in this material is high amount of phenolic compounds present in the olive bagasse (NIAOUNAKIS; HALVADAKIS, 2006), which increase the buffer capacity of the material to be ensiled (MCDONALD et al., 1991) and inhibit the action of lactic acid bacteria during the 
Fermentative profile...

fermentation processes inside the silos (RIDWAN et al., 2015).

The addition of the brans increased the CP contents of the silages obtained due to the amount of protein on the brans (VALADARES FILHO et al., 2006), especially with the addition of soybean meal (Table 3). After the fermentation period, all silages reached the minimum $\mathrm{CP}$ content of $70 \mathrm{~g} \mathrm{~kg}^{-1}$ proposed by Van Soest (1994), in relation to the lower limit for survival and multiplication of microorganisms in the ruminal environment. These results suggest the addition of brans as a promising option for improving levels of CP from silages. However, the high levels of NIDN and NIDA observed suggest caution in the use of residues in ruminant diets.

Foods with high NIDA contents such as those obtained with the silages of this study, indicate foods with low protein value, since this fraction does not suffer ruminal or intestinal
KASPER, N. F.

degradation and is therefore unavailable for animal use (VAN SOEST, 1994).

The behavior observed for the $\mathrm{NH}_{3}-\mathrm{N}$ values at the time of opening of the silos was consistent with the CP levels of the brans used (Table 3), and its increase in relation to the ensilage moment is due to the protein degradation carried out by the proteolytic bacteria whose activity is favored in environments with $\mathrm{pH}$ higher than 4.5 (BARON et al., 1986). In this study, the highest values of $\mathrm{NH}_{3}-\mathrm{N}$ and $\mathrm{pH}$ were observed in the silage added with soybean bran (Table 2, 3). Indicating the development of bacteria, such as those of the genus Clostridium, this group of bacteria when breaking the silage proteins, causes an increase in $\mathrm{pH}$ and favors the production of butyric acid, a weak acid and indicative of low-quality silage (MCDONALD et al., 1991).

Table 3. Nitrogen constituents in olive bagasse silages with food additives at ensilage, at 112 days of fermentation and after seven days of exposure to air

\begin{tabular}{|c|c|c|c|c|c|c|c|c|}
\hline \multirow{3}{*}{ Silages } & \multicolumn{3}{|c|}{ Times } & \multirow{2}{*}{$\begin{array}{c}\text { Averag } \\
\text { e }\end{array}$} & \multicolumn{3}{|c|}{ Times } & \multirow{2}{*}{$\begin{array}{c}\text { Averag } \\
\text { e }\end{array}$} \\
\hline & Ensilage & Opening & Stability & & Ensilage & Opening & Stability & \\
\hline & \multicolumn{4}{|c|}{$\mathrm{CP}\left(\mathrm{g} \mathrm{kg}^{-1}\right.$ of dry matter $)$} & \multicolumn{4}{|c|}{$\mathrm{NH}_{3}-\mathrm{N}\left(\mathrm{g} \mathrm{kg}^{-1}\right.$ of total nitrogen $)$} \\
\hline Bagasse & $50.56 \mathrm{Bc}$ & $76.62 \mathrm{Ab}$ & $78.30 \mathrm{Ac}$ & 68.49 & $1.67 \mathrm{Bb}$ & $21.85 \mathrm{Ac}$ & $3.51 \mathrm{Ba}$ & 9.01 \\
\hline Bagasse+Corn & $61.57 \mathrm{Bc}$ & $76.76 \mathrm{Ab}$ & 76.39Ac & 71.57 & $0.87 \mathrm{Bb}$ & 8.33Ad & 6.10Aa & 5.10 \\
\hline Bagasse+Soybea & 190.50Aa & $131.55 \mathrm{Ba}$ & $126.46 \mathrm{Ba}$ & 149.50 & $3.96 \mathrm{Bb}$ & $40.70 \mathrm{Aa}$ & $3.62 \mathrm{Ba}$ & 15.98 \\
\hline Bagasse+Rice & $98.97 \mathrm{Ab}$ & $74.22 \mathrm{Bb}$ & $106.13 \mathrm{Ab}$ & 93.11 & $8.52 \mathrm{Ba}$ & $27.87 \mathrm{Ab}$ & $5.09 \mathrm{Ba}$ & 13.83 \\
\hline Average & 100.40 & 89.79 & 96.82 & & 3.67 & 24.69 & 4.58 & \\
\hline CV $1(\%)$ & \multicolumn{4}{|c|}{6.93} & \multicolumn{4}{|c|}{17.94} \\
\hline CV $2(\%)$ & \multicolumn{4}{|c|}{9.71} & \multicolumn{4}{|c|}{22.74} \\
\hline & \multicolumn{4}{|c|}{ NIDN ( $\mathrm{g} \mathrm{kg}^{-1}$ of total nitrogen $)$} & \multicolumn{4}{|c|}{ NIDA ( $\mathrm{g} \mathrm{kg}^{-1}$ of total nitrogen) } \\
\hline Bagasse & $351.88 \mathrm{Bc}$ & 414.34BA & $450.67 \mathrm{Ac}$ & 405.63 & $448.17 \mathrm{~A}$ & $319.07 \mathrm{Cb}$ & $384.18 \mathrm{Bc}$ & 383.81 \\
\hline Bagasse + Corn & $725.89 \mathrm{Aa}$ & $483.15 \mathrm{Cba}$ & $628.90 \mathrm{Ba}$ & 612.64 & $457.75 \mathrm{~A}$ & $286.23 \mathrm{Bb}$ & $423.86 \mathrm{Ab}$ & 389.28 \\
\hline Bagasse + Soybea & $614.85 \mathrm{~A}$ & $535.02 \mathrm{Aa}$ & $543.72 \mathrm{Ab}$ & 564.53 & $424.87 \mathrm{Ba}$ & $394.06 \mathrm{Ba}$ & $535.73 \mathrm{Aa}$ & 451.55 \\
\hline Bagasse+Rice & $246.39 \mathrm{Cd}$ & $534.16 \mathrm{Aa}$ & $389.74 \mathrm{Bc}$ & 390.10 & $271.68 \mathrm{~B}$ & $345.07 \mathrm{Ab}$ & $337.21 \mathrm{Ac}$ & 317.99 \\
\hline Average & 484.75 & 491.67 & 503.26 & & 400.62 & 336.11 & 420.25 & \\
\hline CV $1(\%)$ & \multicolumn{4}{|c|}{9.80} & \multicolumn{4}{|c|}{9.37} \\
\hline CV $2(\%)$ & \multicolumn{4}{|c|}{12.55} & \multicolumn{4}{|c|}{10.23} \\
\hline
\end{tabular}

The population of microorganisms of the genus Clostridium in the silages added of soybean bran was similar to the others (Table 6), however, due to the higher availability of substrate, the production of $\mathrm{NH}_{3}-\mathrm{N}$ during ensiling was higher (Table 3). Nevertheless regarding to the added soybean bran on silages, due to the low content of soluble carbohydrates present in the olive bagasse (NIAOUNAKIS; HALVADAKIS, 2006) and the higher availability of fermentable protein compounds, the lactic acid bacteria, which have developed in a similar population in all silages, have used amino acids as a source of energy for microbial growth and release the free ammonia inside the silos (BERNARDES et al., 2005).

The values of the cell wall constituents in the in natura olive bagasse silages (Tab. 4) are coherent with the results described in Nefzaoui (1991). In other silages, the changes observed are due to the composition of the brans (Table 1) 
Fermentative profile...

KASPER, N. F.

(VALADARES FILHO et al., 2006) and are

positive for the nutritional quality of the silages.

Table 4. Cell wall constituents in olive bagasse silages with food additives at ensilage, at 112 days of fermentation and after seven days aerobic exposure

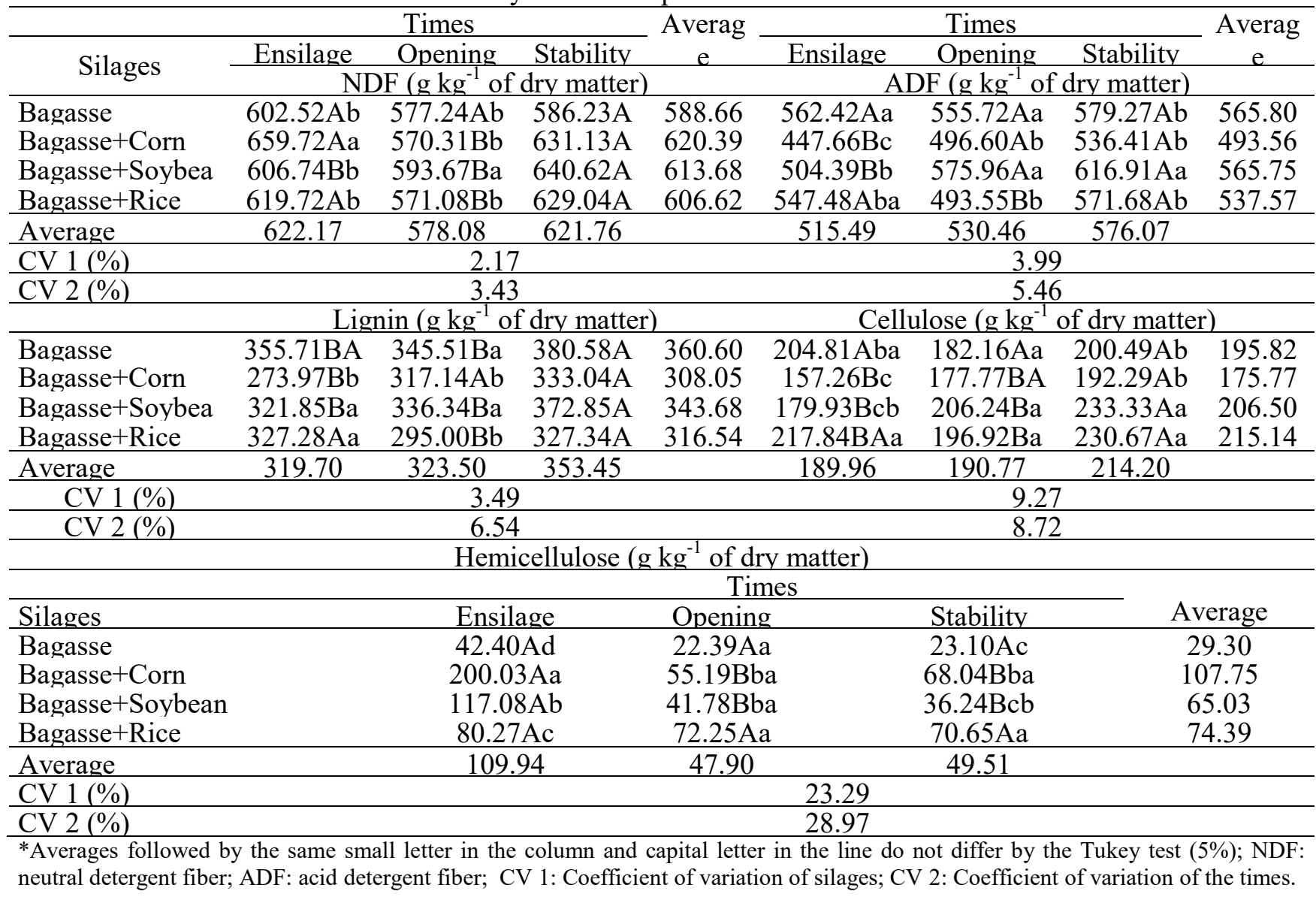

The NDF is a measure of the total insoluble fibers content of the food and is the most used parameter for the balance of ruminant diets (MACEDO JUNIOR et al., 2007). The ADF, because it consists of cellulose and lignin, is indicative of the amount of indigestible material (lignin) or slow digestion the ruminal level (cellulose) (VAN SOEST, 1994). In this study, the NDF decreased in all silages with added bran after the fermentation period due to degradation of hemicellulose by microorganisms as a function of the lower degree of polymerization of these compounds (VAN SOEST, 1994).

Cellulose is formed by long chains of Dglucopyranoses with a high degree of polymerization and high molecular weight (GIGERREVERDIN, 1995), which makes it difficult to break during fermentative processes inside silos, making it a slightly alterable compound in the silages. The susceptibility to enzymatic hydrolysis by fermenters microorganisms of silages and ruminal is even lower when the linear chains join by hydrogen bonds forming microfibrils with a high degree of crystallinity or associated with other polymers of the cellulosic matrix (VAN SOEST, 1994).

In olive bagasse, this susceptibility to degradation is conditioned to lignin and lignocellulosic compounds, whose elimination is linger, especially for the reduction of phenolic compounds (DERMECHE et al., 2013). However, the cellulose present in olive bagasse is associated with a high proportion of xylans and other polysaccharides such as arabinose and galactose, making it highly susceptible to hydrolytic action of enzymes (NIAOUNAKIS; HALVADAKIS, 2006) and potentially usefull for the production of energy both during the biochemical processes inside the silos and the ruminal level.

The lignin contents were diluted in the silages with the addition of the brans, suggesting a possibility of better use of at ruminal level due to the reduction in the constituent most harmful to the use of the fermentable carbohydrates present in the olive bagasse (DERMECHE et al., 2013). 
The hemicellulose has xylan in its composition (SARATALE et al., 2012), whose degradation depends on the action of xylanolytic system, that containing enzymes with different specificities and modes of action. These enzymes are secreted by ruminal microorganisms (VAN SOEST, 1994) and by filamentous fungi (BISWAS et al., 2010), and their action is nutritionally positive, as they promote the break of hemicellulose bonds facilitating subsequent microbial digestion in the rumen (MARTINS et al., 2007). Thus, the observed changes in the hemicellulose contents of the silages are due to the action of xylanases, since, although modest, the growth of filamentous fungi in the ensiled mass was observed (Table 6).

The total carbohydrates (TOHC) were lower in the silage with soybean bran due to the composition of this bran (Table 1) and also showed reduction after fermentation (Table 4) due to the consumption of non-fibrous carbohydrates (FNC) by the microorganisms for production of organic acids and reduction of $\mathrm{pH}$ (Table 2). The changes observed in the NFC (Table 5) in the silages are nutritionally positive, since they are sugars like glucose and fructose and act like reserve for carbohydrates of the plants (starch, fructose and sucrose) (SNIFFEN et al., 1992), therefore with great degradability and great use by the animals (VAN SOEST., 1994). Changes in FC fraction are due to changes in hemicellulose contents (Table 4).

The TDN contents obtained are expressive for silages, since they resemble or exceed values observed in corn silages (DOMINGUES et al., 2012). However, only these high TDN contents do not explain a good nutritional quality silage. Also, the use of additives reduced the contents of TDN, however favored other important characteristics for conservation (Table 2).

Table 5. Carbohydrate and energy fractions (TDN) in olive bagasse silage with food additives in silage, at 112 days of fermentation and stability

\begin{tabular}{|c|c|c|c|c|c|c|c|c|}
\hline \multirow{3}{*}{ Silages } & \multicolumn{3}{|c|}{ Times } & \multirow{2}{*}{ Average } & \multicolumn{3}{|c|}{ Times } & \multirow{2}{*}{ Average } \\
\hline & Ensilage & Opening & Stability & & Ensilage & Opening & Stability & \\
\hline & \multicolumn{4}{|c|}{$\mathrm{TC}\left(\mathrm{g} \mathrm{kg}^{-1}\right.$ of dry matter $)$} & \multicolumn{4}{|c|}{ NFC $\left(\mathrm{g} \mathrm{kg}^{-1}\right.$ of dry matter $)$} \\
\hline Bagasse & $672.16 \mathrm{Ab}$ & $561.51 \mathrm{Cc}$ & $584.32 \mathrm{Bc}$ & 606.00 & $120.90 \mathrm{Aa}$ & $38.62 \mathrm{Bc}$ & $65.31 \mathrm{Bc}$ & 74,94 \\
\hline Bagasse+Corn & 709.10Aa & $628.35 \mathrm{Cb}$ & $649.25 \mathrm{Bb}$ & 662.23 & $134.55 \mathrm{Aa}$ & $131.59 \mathrm{Ab}$ & $85.98 \mathrm{Bcb}$ & 117.37 \\
\hline Bagasse+Soybean & $551.95 \mathrm{Cc}$ & $674.31 \mathrm{Ba}$ & 699.38Aa & 641.88 & $129.46 \mathrm{Ba}$ & 176.28Aa & $177.76 \mathrm{Aa}$ & 161.17 \\
\hline Bagasse+Rice & $696.83 \mathrm{Aa}$ & $688.50 \mathrm{Aa}$ & $658.78 \mathrm{Bb}$ & 681.37 & $121.07 \mathrm{Ba}$ & $186.42 \mathrm{Aa}$ & $102.50 \mathrm{Bb}$ & 136.66 \\
\hline Average & 657.51 & 638.17 & 647.93 & & 126.49 & 133.23 & 107.89 & \\
\hline CV $1(\%)$ & \multicolumn{4}{|c|}{1.27} & \multicolumn{4}{|c|}{15.18} \\
\hline \multirow{2}{*}{ CV $2(\%)$} & \multicolumn{4}{|c|}{1.47} & \multicolumn{4}{|c|}{17.16} \\
\hline & \multicolumn{4}{|c|}{$\mathrm{FC}\left(\mathrm{g} \mathrm{kg}^{-1}\right.$ of dry matter $)$} & \multicolumn{4}{|c|}{ TDN $\left(\mathrm{g} \mathrm{kg}^{-1}\right.$ of dry matter $)$} \\
\hline Bagasse & $553.11 \mathrm{Aa}$ & $525.02 \mathrm{Aa}$ & $527.18 \mathrm{Aa}$ & 535.10 & $638.10 \mathrm{Ca}$ & $756.50 \mathrm{Aa}$ & $704.39 \mathrm{Ba}$ & 699.66 \\
\hline Bagasse + Corn & $575.59 \mathrm{Aa}$ & 497.95Bba & $559.27 \mathrm{Aa}$ & 544.27 & $592.89 \mathrm{Cb}$ & $709.12 \mathrm{Ab}$ & $634.48 \mathrm{Bb}$ & 645.50 \\
\hline Bagasse+Soybean & $423.95 \mathrm{Cb}$ & $485.78 \mathrm{Bb}$ & $532.24 \mathrm{Aa}$ & 480.66 & $623.32 \mathrm{Aa}$ & $526.02 \mathrm{Bd}$ & $419.17 \mathrm{Cd}$ & 522.83 \\
\hline Bagasse+Rice & $582.07 \mathrm{Aa}$ & $503.58 \mathrm{Bba}$ & $557.97 \mathrm{Aa}$ & 547.87 & $499.30 \mathrm{Cc}$ & $606.14 \mathrm{Ac}$ & $525.76 \mathrm{Bc}$ & 543.73 \\
\hline Average & 533.68 & 503.08 & 544.17 & & 588.40 & 649.44 & 570.95 & \\
\hline CV $1(\%)$ & \multicolumn{4}{|c|}{2.72} & \multicolumn{4}{|c|}{1.80} \\
\hline CV $2(\%)$ & \multicolumn{4}{|c|}{3.79} & \multicolumn{4}{|c|}{2.54} \\
\hline
\end{tabular}

The silage added of the rice bran showed higher IVDMD and IVDOM (Table 6). The development stage of the plant during the harvest period may be a possible cause for low digestibility values, perhaps explaining the lower values found in corn and soybean brans added silage, and in the treatment without additives did not differ significantly from the other ones in IVDMD, however, in IVDOM the silage with addition of soybean bran presented lower levels. The silages with corn and soybean obtained higher NIDN fractions, which may have interfered in microbial synthesis, decreasing energy and protein availability affecting silage digestibility. 
Table 6. IVDMD values and IVDOM of olive bagasse silage in natura and with additives, in the ensilage period

\begin{tabular}{lcc}
\hline Treatments & IVDMD $\left(\mathrm{g} \mathrm{kg}^{-1}\right.$ of dry matter $)$ & IVDOM $\left(\mathrm{g} \mathrm{kg}^{-1}\right.$ of dry matter $)$ \\
\hline Bagasse & $602.21 \mathrm{BA}$ & $581.12 \mathrm{BA}$ \\
Bagasse+Corn & $547.03 \mathrm{~B}$ & $511.85 \mathrm{CB}$ \\
Bagasse+Soybean & $545.42 \mathrm{~B}$ & $508.34 \mathrm{C}$ \\
Bagasse+Rice & $625.24 \mathrm{~A}$ & $604.51 \mathrm{~A}$ \\
\hline CV $(\%)$ & 5.82 & 7.22 \\
\hline$P$ value & 0.003 & 0.002 \\
\hline
\end{tabular}

*Averages followed by the same capital letter in the column do not differ by the Tukey test (5\%); CV 1: coefficient of variation of silages. IVDMD - In vitro dry matter digestibility; IVDOM - In vitro digestibility of organic matter.

The microorganisms population has been mainly changed by the study times. The silages demonstrated an increase in the microorganisms population with the fermentation and the aerobic exposure (Table 7). This result confirms that, despite differences in the composition of the studied materials, all provided conditions similar to microbial growth. Even with the non-reduction of $\mathrm{pH}$ below the levels recommended in the silages of the olive bagasse in natura or added of soybean bran (Table 2) no significant development of microorganisms of the genus Clostridium (Table 7) was observed.

Table 7. Populations of microorganisms ( $\log _{10} \mathrm{CFU} \mathrm{g} \mathrm{g}^{-1}$ of dry matter) in silage from olive bagasse with food additives in ensilage, at 112 days of fermentation and after seven days of exposure to air

\begin{tabular}{|c|c|c|c|c|c|c|c|c|}
\hline & \multicolumn{3}{|c|}{ Tempos } & \multirow{2}{*}{ Average } & \multicolumn{3}{|c|}{ Tempos } & \multirow{2}{*}{ Average } \\
\hline \multirow[b]{2}{*}{ Silages } & Ensilage & Opening & Stability & & Ensilage & Opening & Stability & \\
\hline & \multicolumn{3}{|c|}{ Filamentous fungi } & \multicolumn{5}{|c|}{ Clostridium } \\
\hline Bagasse & $0.50 \mathrm{Ca}$ & $7.30 \mathrm{Ba}$ & $9.41 \mathrm{Aa}$ & 5.74 & $0.51 \mathrm{Ca}$ & $3.27 \mathrm{Ba}$ & 9.19Aa & 4.32 \\
\hline Bagasse+Corn & $1.74 \mathrm{Ca}$ & $5.85 \mathrm{Ba}$ & 9.27Aa & 5.62 & $0.46 \mathrm{Ca}$ & $7.28 \mathrm{Ba}$ & 9.19Aa & 5.64 \\
\hline Bagasse + Soybean & $0.48 \mathrm{Ca}$ & $7.56 \mathrm{Ba}$ & $9.45 \mathrm{Aa}$ & 5.83 & $1.48 \mathrm{Ca}$ & $7.52 \mathrm{Ba}$ & $9.26 \mathrm{Aa}$ & 6.09 \\
\hline Bagasse+Rice & $0.48 \mathrm{Ca}$ & $6.61 \mathrm{Ba}$ & 9.88Aa & 5.66 & $0.44 \mathrm{Ca}$ & $7.55 \mathrm{Ba}$ & 9.49Aa & 5.83 \\
\hline Average & 0.80 & 6.83 & 9.50 & & 0.72 & 6.40 & 9.2887 & \\
\hline CV $1(\%)$ & & 24.92 & & & & 13.19 & & \\
\hline \multirow[t]{2}{*}{ CV $2(\%)$} & & 18.45 & & & & 11.36 & & \\
\hline & \multicolumn{3}{|c|}{ Lactobacilus } & \multicolumn{5}{|c|}{ Enterobacteria } \\
\hline Bagasse & $0.51 \mathrm{Ca}$ & $7.25 \mathrm{Ba}$ & 8.99Aa & 5.58 & $0.51 \mathrm{Ca}$ & $3.27 \mathrm{Ba}$ & 8.19Aa & 3.99 \\
\hline Bagasse + Corn & $0.46 \mathrm{Ca}$ & $6.34 \mathrm{Bb}$ & 8.86Aa & 5.22 & $0.46 \mathrm{Ca}$ & $4.07 \mathrm{Ba}$ & 8.00Aa & 4.18 \\
\hline Bagasse + Soybean & $0.48 \mathrm{Ca}$ & 7.69Ba & $9.00 \mathrm{Aa}$ & 5.73 & $0.48 \mathrm{Ba}$ & $1.91 \mathrm{Ba}$ & $9.32 \mathrm{Aa}$ & 3.91 \\
\hline Bagasse+Rice & $0.44 \mathrm{Ca}$ & $7.15 \mathrm{Bba}$ & $9.41 \mathrm{Aa}$ & 5.66 & $0.44 \mathrm{Ca}$ & $3.25 \mathrm{Ba}$ & $8.75 \mathrm{Aa}$ & 4.14 \\
\hline Average & 0.47 & 7.11 & 9.06 & & 0.47 & 3.12 & 8.57 & \\
\hline CV $1(\%)$ & \multicolumn{3}{|c|}{7.87} & \multicolumn{5}{|c|}{39.75} \\
\hline CV $2(\%)$ & \multicolumn{3}{|c|}{9.63} & \multicolumn{5}{|c|}{31.67} \\
\hline
\end{tabular}

* Averages followed by the same small letter in the column and capital letter in the line do not differ by the Tukey test (5\%); CV 2 : coefficient of variation of the times.

The lower development of microorganisms of the genus Clostridium is, the main microorganisms that deteriorate the silages (MOTA et al., 2011), the better is the quality of the silage. In the olive bagasse silage in natura, the poor genus Clostridium population is due to the polyphenol content that acts as a barrier to the microbial development (NIAOUNAKIS; HALVADAKIS, 2006) and dry matter content, which remained above $300 \mathrm{~g} \mathrm{~kg}^{-1}$ (Table 2).
At the evaluation of aerobic stability period during seven days of exposure to air, the $\mathrm{pH}$ values of the four treatments were adapted to the different regression models, generating the following equations: Bagasse $(\hat{\mathrm{Y}}=4.24+0.004 \mathrm{x}) ; \mathrm{R}^{2}=0.68$, Bagasse + Corn $\left(\hat{\mathrm{Y}}=3.80-0.01 \mathrm{x}+0.0002 \mathrm{x}^{2}\right) ; \mathrm{R}^{2}=$ 0.88 , Bagasse + Soybean $(\hat{Y}=4.73+0.004 \mathrm{x}) ; \mathrm{R}^{2}=$ 0.62 and Bagasse + Rice $(\hat{\mathrm{Y}}=3.90-0.006 \mathrm{x}+$ $\left.0.0001 \mathrm{x}^{2}\right) ; \mathrm{R} 2=0.67$. The temperatures of 3 treatments were better adjusted to the quadratic model of regression tested, and the following 
Fermentative profile...

equations were generated for the different treatments: Bagasse $\left(\hat{\mathrm{Y}}=16.10+0.08 \mathrm{x}-0.0004 \mathrm{x}^{2}\right)$; $\mathrm{R}^{2}=0.75$, Bagasse + Corn $(\hat{\mathrm{Y}}=16.78+0.08 \mathrm{x}-$ $\left.0.0004 \mathrm{x}^{2}\right) ; \mathrm{R}^{2}=0.78$, Bagasse + Soybean $(\hat{\mathrm{Y}}=16.63$ $+0.05 x-0.0002)$; R $2=0.70$. However, the silage added from the rice bran showed higher representativity in the linear model $(\hat{\mathrm{Y}}=16.49+$ $0.04 \mathrm{x}) ; \mathrm{R}^{2}=0.72$, and during the stability a linear increase in the temperature of this treatment of $0.04 \%$ was observed at each hour of exposure to air

The $\mathrm{pH}$ is the main factor suppressing the growth of Clostridium, especially in values below 4.2. The increase in $\mathrm{pH}$ values is a practical indication that silage is being degraded due to degradation of organic acids and production of butyric acid. All the silages studied presented aerobic stability for the temperature until the third day of exposure to air, since at no time did they show elevation of more than $1^{\circ} \mathrm{C}$ in relation to the environmental temperature.

The results obtained for the silage temperatures also suggest the non-occurrence of bromatological alterations until $72 \mathrm{~h}$ for all
KASPER, N. F.

treatments and until $120 \mathrm{~h}$ for in natura olive bagasse silage, since according to Bernardes et al. (2007), during changes in the aerobic stability of silages, the elevation of temperature would be tied to changes in nutritive value. Therefore, the consumption of these silages after the breakdown of their aerobic stability would negatively affect their performance when provided to the animals.

\section{CONCLUSIONS}

The bagasse of olive in natura or added of brans can be conserved in the form of silage for use in ruminant diets, since it presents interesting bromatological aspects.

The added silage of the soybean bran provided a greater resistance to the loss of the stability when compared to the others treatments, and until 120 hours of exposure to the air the same did not change in its values of $\mathrm{pH}$ and temperature, that would characterize the beginning of its aerobic deterioration.

RESUMO: Objetivou-se mensurar com esse estudo o perfil bromatológico, microbiológico, características fermentativas e a estabilidade aeróbica das silagens de bagaço de azeitona in natura e aditivada com os farelos de milho, soja e arroz em diferentes tempos de amostragem. Adotou-se o delineamento inteiramente casualizado em arranjo de parcelas subdivididas no tempo 4x3, com quatro repetições. Nas parcelas foram alocados os tratamentos principais e nas sub parcelas foram alocados os tempos de amostragem. As características fermentativas foram estudadas por meio da determinação do conteúdo de matéria seca (MS), pH e nitrogênio amoniacal $\left(\mathrm{N}-\mathrm{NH}_{3}\right)$, o microbiológico por meio da determinação das populações de fungos filamentosos, Clostrídeos, bactérias ácido láticas e enterobactérias. No estudo do perfil nutricional determinouse os conteúdos de matéria mineral (MM), matéria orgânica (MO), proteína bruta (PB), fibra em detergente neutro (FDN), fibra em detergente ácido (FDA), lignina, celulose, hemicelulose, nitrogênio ligado a fibra em detergente ácido (NIDA), nitrogênio ligado a fibra em detergente neutro (NIDN), teores de carboidratos e nutrientes digestíveis totais (NDT). No momento da ensilagem também determinou-se a digestibilidade in vitro da matéria seca (IVDMD) e da matéria orgânica (IVDOM). O uso dos farelos de milho e arroz proporcionou melhor perfil fermentativo nas silagens estudadas. $\mathrm{O} \mathrm{pH}$ das silagens adicionadas de farelo de milho e arroz apresentou-se em 4,00 e 4,06 após os 112 dias de armazenamento, consequentemente. A adição do farelo de soja proporcionou os maiores valores de PB e carboidratos não fibrosos (CNF) após o período fermentativo, sendo de $131,55 \mathrm{~g} / \mathrm{kg}$ de MS para PB e 176,28 g/kg de MS para CNF. Os tratamentos sem adição de farelo e adicionado do farelo de arroz apresentaram teores de DIVMO de (581,12 g/kg de MS) e (604,51 g/kg de MS), consequentemente. Os farelos estudados melhoram o perfil nutricional das silagens avaliadas e são potencialmente utilizáveis como aditivos em silagens de bagaço de azeitona.

PALAVRAS-CHAVE: Silagem. Subproduto. Ruminantes. Valor nutricional.

\section{REFERENCES}

ABAZI, U.; LORITE, I. J.; CÁRCELES, B.; MARTÍNEZ, R.; DURÁN, V. H.; FRANCIA, J. R.; GÓMEZ, J. A. WABOL: A conceptual water balance model for analyzing rainfall water use in olive orchards under different soil and cover crop management strategies. Computers and Electronics in Agriculture, Amsterdam, v. 91, p. 35-48, 2012. https://doi.org/10.1016/j.compag.2012.11.010 
ALCAIDE, E. M.; RUIZ, D. Y. Potential use of olive by-products in ruminant feeding: A review. Animal Feed Science and Technology, Amsterdam, v. 147, p. 247-264, 2008.

https://doi.org/10.1016/j.anifeedsci.2007.09.021

AZEVÊDO, J. A. G.; VALADARES FILHO, S. C.; DETMANN, E. PINA, D. S.; PEREIRA, L. G. R.; OLIVEIRA, K. A. M.; FERNANDES. H. J.; SOUZA, N. K. P. Predição de frações digestíveis e valor energético de subprodutos agrícolas e agroindustriais para bovinos. Revista Brasileira de Zootecnia, Universidade Federal de Viçosa, v. 40, n. 2, p. 391-402, 2011. https://doi.org/10.1590/S151635982011000200022

AZEVÊDO, J. A. G.; VALADARES FILHO, S. C.; PINA, D. S.; DETMANN, E.; VALADARES, R. F. D.; PEREIRA, L. G. R.; SOUZA, N. K. P.; SILVA, L. F. C. Consumo, digestibilidade total, produção de proteína microbiana e balanço de nitrogênio em dietas com subprodutos de frutas para ruminantes. Revista Brasileira de Zootecnia, Universidade Federal de Viçosa, Viçosa, v. 40, n. 5, p. 1052-1060, 2011. https://doi.org/10.1590/S1516-35982011000500017

BARON, V. S.; STEVENSON, K. R.; BUCHANAN-SMITH, J. G. Proteolysis and fermentation of grain-corn ensiled at several moisture levels and under several simulated storage methods.Canadian. Journal Animal Science, Champaign, v. 66, n. 2, p. 451-461, 1986. https://doi.org/10.4141/cjas86-047

BERNARDES, T.F.; REIS, R.A.; MOREIRA, A.L. Fermentative and microbiological profile of Marandu-grass ensiled with citrus pulp pellets. Scientia Agricola, São Paulo, v.62, n.3, p.214-220, 2005.

https://doi.org/10.1590/S0103-90162005000300003

BERNARDES, T.F.; REIS, R. A.; SIQUEIRA, G. R. AMARAL, R. C.; PIRES, A. J. V. Estabilidade aeróbia da ração total e de silagens de capim-Marandu tratadas com aditivos químicos e bacterianos. Revista Brasileira de Zootecnia, Universidade Federal de Viçosa, Viçosa, v. 36, n. 4, p. 754-762, 2007. https://doi.org/10.1590/S1516-35982007000400002

BISWAS, R.; SAHAI, V.; MISHRA, S.; BISARIA, V. S. Bioprocess strategies for enhanced production of xylanase by Melanocarpus albomyces IITD3A on agro-residual extract. Journal of Bioscience and Bioengineering, v. 110, n. 6, p. 702-708, 2010. https://doi.org/10.1016/j.jbiosc.2010.07.013

BOLSEN, K.K.; LIN, C.; BRENT, B. E.; FEYERHERM, A. M.; URBAN, J. E.; AIMUTIS, W. R. Effect of silage additives on the microbial succession and fermentation process of alfalfa and corn silages. Journal of Dairy Science, Amsterdam, v. 75, n. 11, p. 3066-3083, 1992. https://doi.org/10.3168/jds.S00220302(92)78070-9

DRIEHUIS, F.; OUDE ELFERINK, S. J. W. H.; VAN WIKSELAAR, P. G. Fermentation characteristics and aerobic stability of grass silage inoculated with Lactobacillus buchneri, with or without homofermentative latic acid bacteria. Grass and Forage Science, Nova Jersey, v. 56, p. 330-343, 2001. https://doi.org/10.1046/j.13652494.2001.00282.x

DERMECHE, S.; NADOUR, M.; LARROCHE, C.; MOULTI-MATI, F.; MICHAUD, P. Olive mill wastes: Biochemical characterizations and valorization strategies. Process Biochemistry, Amsterdam, v. 48, n. 10, p. 1532-1552, 2013. https://doi.org/10.1016/j.procbio.2013.07.010

FERREIRA, D. F. 2011. Sisvar: a computer statistical analysis system. Ciência e Agrotecnologia, Lavras, v. 35, n. 6, p. 1039-1042, 2011. https://doi.org/10.1590/S1413-70542011000600001

GIGER-REVERDIN, S. Review of the main methods of cell wall estimation: interest and limits for ruminants. Animal Feed Science and Technology, Amsterdam, v. 55, p. 295-334, 1995.

https://doi.org/10.1016/0377-8401(95)00791-K

JAYANEGARA, A.; LEIBER, F.; KREUZER, M. Meta-analysis of the relationship between dietary tannin level and methane formation in ruminants from in vivo and in vitro experiments. Journal of Animal 
Physiology and Animal Nutrition, Berlin, v. 96, n. 3, p. 365-375, 2011. https://doi.org/10.1111/j.14390396.2011.01172.x

KONDO, M.; HIRANO, Y.; KITA, K.; JAYANEGARA, A.; YOKOTA, H. O. Fermentation characteristics, tannin contents and in vitro ruminal degradation of green tea and black tea by-products ensiled at different temperatures. Asian-Australas Journal Animal Science, Gwanak-gu, v. 27, n. 07, p. 937-945, 2014. https://doi.org/10.5713/ajas.2013.13387

MARTINS, S. A.; Vieira P. F.; Berchielli, T. T.; PRADO, I. N.; LEMPP, B.; PAULA, M. C. Degradabilidade in situ e observações microscópicas de volumosos em bovinos suplementados com enzimas fibrolíticas exógenas. Revista Brasileira de Zootecnia, Universidade Federal de Viçosa, Viçosa, v. 36, n. 6, p. 1927-1936, 2007. https://doi.org/10.1590/S1516-35982007000800029

MCDONALD, P.; HENDERSON, A.R.; HERON, S. The biochemistry of silage. 2 ed: Marloui:Chalcome, 1991, 340p.

MOTA, A. D. S.; JÚNIOR, V. R. R.; SOUZA, A. S.; REIS, S. T.; TOMICH, T. R.; CALDEIRA, L. C.; MENEZES, G. C. C.; COSTA, M. D. Perfil de fermentação e perdas na ensilagem de diferentes frações da parte aérea de quatro variedades de mandioca. Revista Brasileira de Zootecnia, Universidade Federal de Viçosa, Viçosa, v. 40, n. 7, p. 1466-1473, 2011. https://doi.org/10.1590/S1516-35982011000700010

NASOPOULOU, C.; ZABETAKIS, I. Agricultural and Aquacultural Potential of Olive Pomace: A Review. Journal of Agricultural Science, Toronto, v. 5, n. 7, p. 116-128, 2013. https://doi.org/10.5539/jas.v5n7p116

NEFZAOUI, A. Valorisation des sous-produits de l'olivier. Fourrage setsous-produits méditerranéens, (Options Méditerranéennes: Série A. Séminaires Méditerranéens), n. 16, p. 101-108, 1991.

NERES, M. A.; ZAMBOM, M. A.; FERNANDES, T.; CASTAGNARA, D. D.; RODRIGUES, J. F. H.; TAFFAREL, L. E.; JAVORSKI, C. R.; POZZA, M. S. S. Microbiological profile and aerobic stability of Tifton 85 bermudagrass silage with different additives. Revista Brasileira de Zootecnia, Universidade Federal de Viçosa, Viçosa, v. 42, n. 6, p. 381-387, 2013. https://doi.org/10.1590/S1516-35982013000600001

NIAOUNAKIS, M.; HALVADAKIS, C. P. 2006. Olive Processing Waste Management Literature Rewiew and Patent Survey In: Wast Management Series, Second ed. v. 5. Elsevier, 2006. 498p.

OMAR, J. M. A.; DAYA, R.; GHALEB, A. Effects of different forms of olive cake on the performance and carcass quality of Awassi lambs. Animal Feed Science and Technology, Amsterdam, v. 171, p. 167-172, 2012. https://doi.org/10.1016/j.anifeedsci.2011.11.002

RIDWAN, R.; RUSMANA, I.; WIDYASTUTI, Y.; WIRYAWAN, K. G.; PRASETYA, B.; SAKAMOTO, M.; OHKUMA, M. Fermentation Characteristics and Microbial Diversity of Tropical Grass-legumes Silages.

Asian-Australasian Journal of Animal Science, Gwanak-gu, v. 28, n. 4, p. 511-518, 2015. https://doi.org/10.5713/ajas.14.0622

SANSOUCY, R., ALIBES, X., BERGE, P, H. et al. Olive by-products for animal feed. FAO Animal Production Health Paper 43, 1985.

SARATALE, G. D.; SARATALE, R. G.; Oh, S. E. Production and characterization of multiple cellulolytic enzymes by isolated Streptomyces sp. MDS. Biomass and Bioenergy, Amsterdam, v. 47, p. 302-315, 2012. https://doi.org/10.1016/j.biombioe.2012.09.030

SILVA, N.; JUNQUEIRA, V.C.A.; SILVEIRA, N.F.A. et al. Manual de métodos de análise microbiológica de alimentos. 3 ed. São Paulo: Livraria Varela, 2007. 45-60p.

SILVA, D.J.; QUEIROZ, A.C. Análise de alimentos: métodos químicos e biológicos. 3 ed. Universidade Federal de Viçosa, 2009. 235p. 
SNIFFEN, C. J.; O'CONNOR, J. D.; VAN SOEST, P. J.; FOX, D. G.; RUSSEL, J. B. A net carbohydrate and protein system for evaluating cattle diets: II. Carbohydrate and protein availability. Journal of Animal Science, Champaign, v. 70, n. 12, p. 3562-3577, 1992. https://doi.org/10.2527/1992.70113562x

VALADARES FILHO, S.C.; MAGALHÃES, K.A.; ROCHA J.R. et al. Tabelas brasileiras de composição de alimentos para bovinos. 2 ed. Viçosa, MG: UFV, 2006. 239p.

VAN SOEST, P. J.; ROBERTSON, J. B.; LEWIS, B. A. Methods for dietary fiber, neutral detergent fiber, and non starch polyssacarides in relation to animal nutrition. Journal of Dairy Science, Madison, v. 74, n. 10, p. 3583- 3597, 1991. https://doi.org/10.3168/jds.S0022-0302(91)78551-2

VAN SOEST, P. J. Nutritional ecology of the ruminant. Ithaca. Constock Publishing Associates, 1994. 476 p. 